Daianne Teixeira Soares'

Telmara Menezes Couto ${ }^{2}$

Ridalva Dias Martins ${ }^{3}$

Jules Ramon Brito Teixeira ${ }^{4}$ Jaqueline Alves Pires 5

Gleice de Oliveira Santos ${ }^{6}$

\title{
Sociodemographic and Clinical Factors Associated with Postpartum Hemorrhage in a Maternity Ward*
}

Theme: Evidence-based practice.

Contribution to the discipline: The study generated information capable of supporting strategies that can contribute to the reduction of postpartum hemorrhage and maternal mortality.

\section{ABSTRACT}

Objective: Checking the sociodemographic and clinical factors associated with the prevalence of postpartum hemorrhage (PPH) in a maternity school. Materials and methods: A quantitative cross-sectional study in a maternity hospital in Salvador, Bahia, Brazil. In data collection, we used a standardized form that contained sociodemographic and clinical data from the medical records of 83 women for the period of 2018. Stata version 14 software was used in the analyses. Bivariate analysis was conducted using Pearson's or Fisher's exact tests. Poisson regression was performed with robust variation in multivariate analysis. Prevalence ratios (PR) and

\footnotetext{
* This article is derived from the master's thesis entitled "Sociodemographic and clinical factors associated with postpartum hemorrhage in a maternity school", presented to the Graduate Program in Nursing of the Universidade Federal da Bahia, Brazil.

$1 \bowtie$ https://orcid.org/0000-0002-3025-9844. Empresa Brasileira de Serviços Hospitalares, Universidade Federal da Bahia, Brazil. daianne.soares@ebserh.gov.br

2 https://orcid.org/0000-0001-6836-8563. Universidade Federal da Bahia, Brazil. telmara.couto@ufba.br

3 https://orcid.org/0000-0003-0295-9998. Universidade Federal da Bahia, Brazil. ridalvamartins@ufba.br

4 https://orcid.org/0000-0002-8443-7810. Universidade Estadual de Feira de Santana, Brazil.

5 https://orcid.org/0000-0002-5993-4567. Universidade Federal da Bahia, Brazil. jaquelineap@ufba.br

6 https://orcid.org/0000-0002-7582-8465. Universidade Federal da Bahia, Brazil. santos.gleice@ufba.br
} 
respective $95 \%$ confidence intervals were estimated. The significance level of the tests was $5 \%$. Results: The prevalence of PPH was $38.6 \%$ and $25.6 \%$ for atony as the cause. In the bivariate analysis, there was an association between PPH and non-breastfeeding in the first hour of life $(p=0.039)$. In the multivariate analysis, it was identified that multiparous women had an increase in the prevalence of $\mathrm{PPH}$ by almost twice (PR = 1.97). Not breastfeeding in the first hour of life increased this prevalence more than four times (PR $=4.16)$. Conclusions: Monitoring multiparous women during birth care and encouraging breastfeeding in the first hour of life may decrease the prevalence of $\mathrm{PPH}$.

KEYWORDS (SOURCE: DeCS)

Postpartum Hemorrhage; Maternal Mortality; Breast Feeding; Parity; Nursing Care. 


\section{Factores sociodemográficos y clínicos asociados a la hemorragia posparto en una maternidad*}

\section{RESUMEN}

Objetivo: investigar los factores sociodemográficos y clínicos asociados a la prevalencia de hemorragia posparto (HPP) en una maternidad de enseñanza. Materiales y métodos: estudio cuantitativo de corte transversal, en una maternidad de Salvador, Bahia, Brasil. En la recolección de los datos, se empleó formulario estandarizado que contenía datos sociodemográficos y clínicos de los historiales de 83 mujeres referentes al período de 2018. En los análisis, se utilizó el software STATA versión 14. Se realizó análisis bivariado, por medio de las pruebas de Pearson o exacto de Fisher. Además, regresión de Poisson con variación robusta en el análisis multivariado. Se estimaron razones de prevalencia (RP) y respectivos intervalos de confianza del $95 \%$. El nivel de significancia de las pruebas fue del $5 \%$. Resultados: la prevalencia de HPP fue del 38,6 \% y del 25,6 \% para atonía como causa. En el análisis bivariado, se evidenció asociación entre HPP y no lactancia en la primera hora de vida $(p=0,039)$. En el análisis multivariado, se identificó que mujeres multíparas tuvieron incremento en la prevalencia de HPP en casi dos veces $(\mathrm{RP}=1,97)$. No lactar en la primera hora de vida aumentó esta prevalencia en más de cuatro veces $(\mathrm{RP}=4,16)$. Conclusiones: monitorear multíparas durante la asistencia al parto e incentivar la lactancia materna en la primera hora de vida puede reducir la prevalencia de la HPP.

\section{PALABRAS CLAVE (Fuente: DeCS)}

Hemorragia posparto; mortalidad materna; lactancia materna; paridad; atención de enfermería.

\footnotetext{
* El artículo se deriva de la tesis de maestría titulada "Factores sociodemográficos y clínicos asociados a la hemorragia posparto en una maternidad escuela", presentada al Programa de Posgrado en Enfermería de la Universidade Federal da Bahia, Brasil.
} 


\section{Fatores sociodemográficos e clínicos associados à hemorragia pós-parto numa maternidade*}

\section{RESUMO}

Objetivo: investigar os fatores sociodemográficos e clínicos associados à prevalência de hemorragia pós-parto (HPP) em uma maternidade escola. Materiais e métodos: estudo quantitativo de corte transversal, numa maternidade de Salvador, Bahia, Brasil. Na coleta de dados, utilizou-se formulário padronizado que continha dados sociodemográficos e clínicos dos prontuários de 83 mulheres referentes ao período de 2018. Nas análises, utilizou-se o software STATA versão 14. Foi conduzida análise bivariada, por meio dos testes de Pearson ou exato de Fisher. Realizou-se regressão de Poisson com variação robusta na análise multivariada. Foram estimadas razões de prevalência (RP) e respectivos intervalos de confiança de $95 \%$. 0 nível de significância dos testes foi de 5 \%. Resultados: a prevalência de HPP foi de $38,6 \%$ e de $25,6 \%$ para atonia como causa. Na análise bivariada, evidenciou-se associação entre HPP e não amamentação na primeira hora de vida $(\mathrm{p}=0,039)$. Na análise multivariada, identificou-se que mulheres multíparas tiveram incremento na prevalência de HPP em quase duas vezes ( $R P=1,97)$. Não amamentar na primeira hora de vida aumentou essa prevalência em mais de quatro vezes $(R P=4,16)$. Conclusões: monitorizar multíparas durante a assistência ao parto e incentivar 0 aleitamento materno na primeira hora de vida pode diminuir a prevalência de HPP.

\section{PALAVRAS-CHAVE (Fonte: DeSC)}

Hemorragia pós-parto; mortalidade materna; aleitamento materno; paridade; cuidados de enfermagem.

\footnotetext{
* Este artigo é derivado da dissertação de mestrado intitulada "Fatores sociodemográficos e clínicos associados à hemorragia pós-parto em uma maternidade escola", apresentada ao Programa de Pós-Graduação em Enfermagem da Universidade Federal da Bahia, Brasil.
} 


\section{Introduction}

Postpartum hemorrhage (PPH) is a serious public health problem that is the obstetric complication with the highest maternal mortality rate in the world. It is traditionally defined as blood loss above $500 \mathrm{ml}$ after vaginal birth or above $1000 \mathrm{ml}$ after cesarean birth in the first 24 hours or any blood loss by the genital tract capable of causing hemodynamic instability.

In Brazil, it is configured as the second cause of maternal mortality, the first being pregnancy-specific hypertension, the third puerperal infection, and abortion as the fourth cause (1). Besides being responsible for maternal deaths, PPH can cause serious complications such as maternal shock, respiratory disease distress syndrome, coagulopathy, and secondary infertility, and most cases are preventable if there are conditions to put into practice current evidence on prevention and control of this morbidity (3).

Maternal death occurs in less than $1 \%$ of pregnancies in most developed countries and between $25 \%$ and $30 \%$ occur due to $\mathrm{PPH}$. A worldwide loss of 150,000 lives per day is estimated because of PPH; $88 \%$ of them occur in the first four hours of postpartum. The maternal mortality ratio in developed regions such as the United States and Canada in 2015 was 12 per 100,000 live births (LB), while in developing regions it was 239 per 100,000, much higher than the wealthier regions. In this sense, a study found that $99 \%$ of maternal deaths were concentrated in developing countries and more than half of them occurred in contexts of crises, inadequate environments, and devoid of resources, which emphasizes social and economic inequalities between classes (1).

Estimates from the World Health Organization (WHO) indicate that in 2013 there were 287,000 maternal deaths worldwide, with a maternal death ratio (MDR) of 385 to 210 per 100,000 LB in a time frame from 1990 to 2013. In Latin America and the Caribbean, 8,800 maternal deaths were estimated, and the MDR reduced from 140 to 85 per $100,000 \mathrm{LB}$, which indicates a reduction in rates compared to 1990. In Brazil, according to these estimates, the MDR decreased in the same period from 120 to 69 per 100,000 LB - a drop of $43 \%$. But to achieve the goal of the fifth-millennium goal, Brazil should have presented an estimated MDR of 35 deaths per 100,000 LB (4).

The MDR in Brazil increased from 62 to 64 per 100,000 live births between 2015 and 2017, with an increasing difference between Brazilian regions: South - 38.5; Midwest - 56.9; South- east - 62.3; Northeast -73.2 and North -88.9 per 100,000 LB. The Northeast region had the highest number of cases of maternal mortality due to PPH with $34.5 \%(n=719)$, while the South had the lowest with $16.5 \%(n=345)$. Significant regional differences are observed in Brazil, ranging from 95 per 100,000 LB in the Northeast region, in Salvador 60 per 100,000 LB, to 41 per 100,000 LB in the South region, which shows more than twice the ratio. Variations in the mortality rate may be associated with the quality of care provided during the pregnancy and puerperal period and the information obtained through death surveillance $(5,6)$.

Brazil did not meet its commitment to arrive in 2015 with a maximum of 35 maternal deaths per $100,000 \mathrm{LB}$, agreed on by the millennium goals. Between 2016 and 2030, as part of the Sustainable Development Goals, the goal is to reduce the overall maternal mortality rate to less than 30 per 100,000 LB $(1,6)$.

Inequalities in access to health services contribute to many women experiencing these complications, during or after childbirth, as is the case of PPH (1). The effectiveness of the prevention of PPH and the decrease in maternal mortality is closely related to the social and economic situation present in developing countries. Less favored areas, associated with socio-demographic issues, poverty, misery, and unfavorable financial conditions, expose women to more risks. In this sense, the frequency of injuries, such as PPH and its repercussion on maternal mortality, becomes an indicator of inequity and disparity between men and women, as well as an important indicator of the population's health condition, socioeconomic development, and the guarantee of women's rights $(3,4)$.

When death does not occur, the woman may have non-fatal complications such as hypotension and fatigue (impairing motherchild contact), important anemia, coagulopathy, need for blood transfusion and its possible complications, pituitary ischemia, and hypopituitarism (Sheehan syndrome), reduction of lactation, myocardial ischemia, and complications of surgical treatment. More than $50 \%$ of all maternal morbidity during pregnancy results from obstetric hemorrhage (1).

Inserted in this context, Brazil is in a scenario of intense medicalization of the birth process, with $98 \%$ of deliveries performed in hospitals and with good prenatal coverage, while persisting high rates of maternal morbidity and mortality with an index of 69 per 100,000 LB, which represents more than double the assumed goal (1). 
PPH is a significant contributor to severe maternal morbidity and prolonged disability, so nursing professionals should be alert for PPH symptoms and prepared to act and respond quickly and effectively. Oxytocin after childbirth is the main action to prevent $\mathrm{PPH}$, a medication of first choice, and may reduce cases of $\mathrm{PPH}$ by uterine atony by more than $50 \%$. Early control of the bleeding site is the most effective measure in the treatment of $\mathrm{PPH}(1,2,5)$. Thus, the nursing professional and the health team play a crucial role in ensuring hemostasis in the postpartum period, to reduce blood loss and control PPH $(6,7)$.

Considering the magnitude of $\mathrm{PPH}$, which is an increasingly frequent problem in health systems and could be prevented in up to $90 \%$ of cases, this theme becomes an important object of study capable of offering subsidies in the creation of strategies that can promote improvements in the quality of care provided by the nursing team to women's health. For this, there must be early identification, adequate treatment, provision of information and educational actions in health, approach to harm reduction and contribution of scientific evidence. In this sense, it is necessary to better understand the phenomenon, which justifies the realization of this study, which aimed to investigate the sociodemographic and clinical factors associated with PPH in a maternity school.

\section{Materials and method}

This is a cross-sectional study with a retrospective collection. It was developed in a maternity school in Salvador, Bahia, Brazil, from January to December 2018.

The study population was represented by 83 women who attended the prepartum of this maternity. We included women who had a normal or cesarean birth, at the study site and during the data collection period. As an exclusion criterion, women who had abortions, fetal deaths, and stillborn.

For data collection, a standardized form was used, based on information of interest for the study, which was available in the participants' medical records. The explanatory variables analyzed were sociodemographic (age, race, education, marital status, occupation, religion, residence and maternity linkage) and clinics (current birth route, dystocia, pharmacological induction, risk classification, birth position, use of light technologies, birth care performed by a doctor or obstetric nursing professional, breastfeeding in the first hour of life). The outcome under study was PPH.

Stata software, version 14, was used for data processing and data processing. For categorical variables, absolute and relative frequencies were estimated; for quantitative variables with normal distribution, minimum and maximum values, mean and standard deviation were estimated. Prevalence was estimated and the Pearson Chi-square test or Fisher's exact test for the comparison of percentages with a significance level of $5 \%$. The measure of association used was the prevalence ratio (PR) and their respective confidence intervals of $95 \%$ (CI = 95\%). The variables with $p$-value $\leq 0.20$ in the bivariate model were inserted in the multivariate model. To determine the most parsimonious final model, the lowest value of Akaike Information Criterion (AIC) was considered. This study has the approval of the ethics committee in maternity research in which it was conducted, with Opinion n. ${ }^{\circ} 3,426,869$.

\section{Results}

We interviewed 83 women who attended in a maternity hospital in Salvador, Bahia. When analyzing the prevalence of PPH according to sociodemographic characteristics, there was a predominance of age from 18 to 29 years old (51.8\%), black (94\%), high school/higher education (62.7\%), with a prevalence of high school $(55.4 \%)$, without a partner (83.1 \%), with work outside the home $(50.6 \%)$, with religion $(84.5 \%)$ and residents in Salvador or metropolitan region (71.1\%), predominantly Salvador (60.2\%). It was found that $71(85.5 \%)$ of the participants had no connection with motherhood (Table 1).

On the clinical characteristics of childbirth, the prevalence of $\mathrm{PPH}$ was $38.6 \%$, with causes attributed to atony (25.6\%), followed by laceration (7.2 \%), trauma (3.6\%) and coagulation disorder $(1.2 \%)$. In this maternity ward, the variable route of birth found a higher frequency of cesarean sections (59\%), lower dystocia (12\%) and pharmacological induction (39.8\%). There was homogeneous distribution in high-risk deliveries (56.6\%) and usual risk (43.4\%), with a predominance of horizontal position (73.5 \%) together with medical care (84.3\%). To a lesser extent, light technologies were used (24.1\%) and breastfeeding in the first hour of life (18.1\%). In the bivariate analysis, there was an association between PPH and non-breastfeeding in the first hour of life ( $p$-value $=0.039)$ (Table 2). 
Table 1. Prevalence of postpartum hemorrhage and prevalence ratio, according to sociodemographic characteristics. Bahia, $2020(\mathrm{~N}=83)$

\begin{tabular}{|c|c|c|c|c|c|c|c|}
\hline Variables & $\%$ & $\mathrm{n}$ & $\mathbf{N}$ & $\mathbf{P}$ & p-value* & PR & $\mathrm{Cl}=95 \%$ \\
\hline \multicolumn{8}{|l|}{ Age group } \\
\hline$<18$ years old & 10.8 & 3 & 9 & 33.3 & 0.867 & 1.00 & - \\
\hline From 18 to 29 years old & 51.8 & 16 & 43 & 37.2 & & 1.12 & $0.41-3.06$ \\
\hline 30 or over & 37.3 & 13 & 31 & 41.9 & & 1.26 & $0.45-3.48$ \\
\hline \multicolumn{8}{|l|}{ Race / color } \\
\hline Not black & 6.0 & 4 & 5 & 80.0 & 0.070 & 1.00 & - \\
\hline Black & 94.0 & 28 & 78 & 35.9 & & 0.45 & $0.26-0.76$ \\
\hline \multicolumn{8}{|l|}{ Schooling } \\
\hline Elementary school & 37.3 & 9 & 31 & 29.0 & 0.169 & 0.66 & $0.34-1.24$ \\
\hline High school/higher education & 62.7 & 23 & 52 & 44.2 & & 1.00 & - \\
\hline \multicolumn{8}{|l|}{ Marital status } \\
\hline No mate & 83.1 & 30 & 69 & 43.5 & 0.068 & 1.00 & - \\
\hline With mate & 16.9 & 2 & 14 & 14,3 & & 0.32 & $0.09-1.23$ \\
\hline \multicolumn{8}{|l|}{ Occupation } \\
\hline Housewife & 49.4 & 14 & 41 & 34.2 & 0.415 & 1.00 & - \\
\hline Works away from home & 50.6 & 18 & 42 & 42.9 & & 1.26 & $0.72-2.18$ \\
\hline \multicolumn{8}{|l|}{ Religion } \\
\hline Yes & 84.5 & 20 & 49 & 40.8 & 0.673 & 1.00 & - \\
\hline No & 15.5 & 3 & 9 & 33.3 & & 0.82 & $0.30-2.20$ \\
\hline \multicolumn{8}{|l|}{ Residence } \\
\hline Salvador/metropolitan area & 71.1 & 20 & 59 & 33.9 & 0.172 & 1.00 & - \\
\hline Countryside & 28.9 & 12 & 24 & 50.0 & & 1.48 & $0.86-2.53$ \\
\hline \multicolumn{8}{|l|}{ Link with maternity } \\
\hline Yes & 14.5 & 2 & 12 & 16.7 & 0.117 & 1.00 & - \\
\hline No & 85.5 & 30 & 71 & 42.3 & & 2.54 & $0.69-9.32$ \\
\hline
\end{tabular}

$\%$ percentage concerning the total number of women, with data for each variable; $\mathrm{n}$ : number of women with PPH; $\mathrm{N}$ : number of women in each category; $\mathrm{P}$ : prevalence; $\mathrm{PR}$ : prevalence ratio; $\mathrm{CI}=$ $95 \%$ : $95 \%$ confidence interval ; *p-value obtained by Fisher Chi-square or Exact Test.

Source: Own elaboration. 
Table 2. Prevalence of postpartum hemorrhage and prevalence ratio, according to clinical characteristics of childbirth. Bahia, $2020(\mathrm{~N}=83)$.

\begin{tabular}{|c|c|c|c|c|c|c|c|}
\hline Variables & $\%$ & $n$ & $\mathrm{~N}$ & $\mathbf{P}$ & p-valor* & PR & $\mathrm{Cl}=95 \%$ \\
\hline \multicolumn{8}{|l|}{ Type of birth route } \\
\hline Normal birth & 41.0 & 14 & 34 & 41.2 & 0.683 & 1.00 & - \\
\hline Cesarean & 59.0 & 18 & 49 & 36.7 & & 0.89 & $0.52-1.54$ \\
\hline \multicolumn{8}{|l|}{ Dystocia } \\
\hline No & 88.0 & 28 & 73 & 38.4 & 1.000 & 1.00 & - \\
\hline Yes & 12.0 & 4 & 10 & 40.0 & & 1.04 & $0.46-2.36$ \\
\hline \multicolumn{8}{|l|}{ Pharmacological induction } \\
\hline No & 60.2 & 20 & 50 & 40.0 & 0.739 & 1.00 & - \\
\hline Yes & 39.8 & 12 & 33 & 36.4 & & 0.90 & $0.52-1.60$ \\
\hline \multicolumn{8}{|l|}{ Risk rating } \\
\hline Usual risk & 43.4 & 14 & 36 & 38.9 & 0.956 & 1.00 & - \\
\hline High risk & 56.6 & 18 & 47 & 38.3 & & 0.98 & $0.57-1.71$ \\
\hline \multicolumn{8}{|l|}{ Birth position } \\
\hline Horizontal & 73.5 & 25 & 61 & 41.0 & 0.449 & 1.00 & - \\
\hline Vertical & 26.5 & 7 & 22 & 31.8 & & 0.78 & $0.39-1.54$ \\
\hline \multicolumn{8}{|l|}{ Use of lightweight technologies } \\
\hline Yes & 24.1 & 8 & 20 & 40.0 & 0.879 & 1.00 & - \\
\hline No & 75.9 & 24 & 63 & 38.1 & & 0.95 & $0.51-1.78$ \\
\hline \multicolumn{8}{|l|}{ Childbirth care } \\
\hline Doctor & 84.3 & 28 & 70 & 40.0 & 0.758 & 1.00 & - \\
\hline Professional nursing Obstetrician & 15.7 & 4 & 13 & 30.8 & & 0.77 & $0.32-1.83$ \\
\hline \multicolumn{8}{|c|}{ Breastfeeding in the first hour of life } \\
\hline Yes & 18.1 & 2 & 15 & 13.3 & 0.039 & 1.00 & - \\
\hline No & 81.9 & 30 & 68 & 44.1 & & 3.30 & $0.88-12.46$ \\
\hline
\end{tabular}

Source: own elaboration.

It is important to highlight in the results that, in the normal birth group, the variable birth care allows us to analyze that the care provided by the physician predominates in this maternity ward (60\%), in relation to the obstetric nursing professional (40\%), and, compared to physicians, there was a higher proportion of use of light technologies in childbirth care by obstetric nursing profession- als (p-value $=0.001)$, with a statistically significant difference. In the multivariate analysis (Table 3), adjusted for schooling, it was identified that multiparous women (with three or more previous pregnancies) had an increase in the prevalence of PPH by almost twice (PR = 1.97). Not breastfeeding in the first hour of life increased this prevalence more than four times $(P R=4.16)$. 
Table 3. Adjusted prevalence ratios and confidence intervals (95\%) factors associated with postpartum hemorrhage. Bahia, 2019

\begin{tabular}{|l|c|c|}
\hline Variables & ${\text { PR } \text { Adjusted }^{\mathrm{a}}}^{\mid}$ & $\mathrm{Cl}=\mathbf{9 5} \%$ \\
\hline Previous pregnancies & 1.00 & - \\
\hline Up to 2 & 1.97 & $1.14-3.42$ \\
\hline 3 or more & 1.00 & - \\
\hline Breastfeeding in the first hour of life \\
\hline Yes & 4.16 & $1.17-14.80$ \\
\hline No & \multicolumn{2}{|c|}{1,5003} \\
\hline AIC &
\end{tabular}

${ }^{a}$ Model adjusted by the variable schooling.

Source: Own elaboration.

\section{Discussion}

The diagnosis of PPH presented a high prevalence in this study, and the investigation of associated sociodemographic and clinical factors inserted in this problem becomes important for the contribution of the prevention of this disease and reduction of maternal mortality. The present study presents statistical significance in the bivariate analysis, which evidences an association between PPH and non-breastfeeding in the first hour of life. In the multivariate analysis, it was identified that multiparous women (with three or more previous pregnancies) had an increase in the prevalence of PPH by almost twice (PR $=1.97)$. Not breastfeeding in the first hour of life increased this prevalence more than four times $(P R=4.16)$.

Regarding the sociodemographic variables, it was noted that there was no statistical significance with PPH. When investigating the prevalence of PPH in women according to their age group, the predominance of age from 18 to 29 years old $(51.8 \%)$ and no studies that associate age range alone with PPH are found, but a study was identified that analyzed the variable maternal age associated with greater complications in childbirth, causing more cesarean sections, which aggravates the risk, increases the frequency of PPH and, consequently, maternal death.

Regarding the color variable, the black one predominated in this study without presenting a statistically significant association between the variable race and $\mathrm{PPH}$. However, it is important to highlight those women who had PPH predominantly declared themselves black ( $94 \%$ ), due to the higher concentration of this breed in Brazil and that black women end up being more susceptible to morbidities that result in maternal death. This is due not to this race being a risk factor, but to social inequalities and the difficulty of access of this population to health services, while it has the highest rate of public service users in Brazil $(8,9)$.

The level of education in this study presented predominant distribution in women who had access to high school (62.7\%), and a variable that is necessary to investigate when addressing women in the scope of health promotion, protection, and recovery behaviors. In this regard, research has proven that younger adults with low schooling are less regularly exposed to preventive tests, indicating the presence of inequalities in the use of services (8).

Regarding the variable marital status, there was a predominance of women without a partner (83\%). It is important to think about unofficially and/or open marital relationships since it is frequent to break the relationship between the baby's father and mother, and/or make different decisions when discovering a pregnancy. These ruptures generate the woman's lack of support and support from a network, if solo mothers, as well as widows and divorcees, have the propensity to make up an unprotected group. The arguments for this are justified due to the absence, for the most part, of affective, emotional, social, financial, and encouragement to self-care, both by the baby's father and family. The presence of a partner during the gestational period is relevant, as it can provide emotional and financial support to the pregnant woman and prevent maternal complications (10).

Regarding the occupation of women, there was a homogeneous distribution among the variable data, being from the home $(50.6 \%)$ and workers outside the home (49.4\%). This allows an analysis that a significant portion of these women are not in the labor market, do not have a job relationship or paid employment outside the home. This finding is in line with the patriarchal mod$\mathrm{el}$, in which the man (father, husband) is seen as a provider and caretaker of the family, responsible for the support of the house, leaving it to work, and in which the woman fulfills her role as wife, mother and housewife (11).

Regarding the variable marital status, there was a predominance of women without a partner (83\%). It is important to think about unofficially and/or open marital relationships, since it is 
frequent to break the relationship between the baby's father and mother, and/or make different decisions when discovering a pregnancy. These ruptures generate the woman lack of support and support from a network, if solo mothers, as well as widows and divorcees, have the propensity to make up an unprotected group. The arguments for this are justified due to the absence, for the most part, of affective, emotional, social, financial and encouragement to self-care, both by the baby's father and family. The presence of a partner during the gestational period is relevant, as it can provide emotional and financial support to the pregnant woman and prevent maternal complications (10). Regarding the occupation of women, there was a homogeneous distribution among the variable data, being from the home (50.6\%) and workers outside the home (49.4\%). This allows an analysis that a significant portion of these women are not in the labor market, do not have a job relationship or paid employment outside the home. This finding is in line with the patriarchal model, in which the man (father, husband) is seen as a provider and caretaker of the family, responsible for the support of the house, leaving it to work, and in which the woman fulfills her role as wife, mother and housewife (11).

Regarding religion, there was a predominance of women with religion $(84.5 \%)$ and the finding of the absence of this information in $30.1 \%$ of the medical records. This reveals the underreporting of religion by professionals who perform the admission of women and consequently generates a limitation in this study to better analyze the distribution of this variable.

On the clinical variables, the prevalence results of $\mathrm{PPH}$ found in this study (38.6\%) differ from national and international literature ranging from $5 \%$ to $15 \%$, ranging from $2 \%$ to $4 \%$ in normal deliveries and 6 to $7 \%$ in cesarean deliveries (1). The prevalence of PPH in Brazil may be even higher, since the disease is highly underreported, especially in the Northeast region, which has the highest rate of underreporting of maternal mortality, parallel to characteristics such as high percentage of illiteracy, greater public vulnerability due to economic income, social deficiencies and problems found to access health services and make use of them (7).

Regarding the causes attributed to PPH in this study, they are in accordance with current scientific evidence that is highlighted worldwide for uterine atony ( $80 \%$ ), followed by path lacerations, placental retention, and coagulation disorders (1).

The results show that the predominant mode of birth was cesarean section (59\%), and the minority presented dystocia (12\%).
The prevalence of cesarean section in this maternity ward is higher than that recommended by the WHO (15\%), a factor that corroborates negative outcomes, higher rate of complications, higher prevalence of $\mathrm{PPH}$ and contributes to the increase in maternal mortality rates. In this sense, to ensure the safety of women and their children, normal birth should be encouraged because it is associated with fewer negative outcomes (12).

The variable induction of birth can be observed in $39.8 \%$, and most of these inductions were performed without a clear indication, inferring that it is a non-standardized care routine. The drugs used in this case, such as oxytocin alone, the association with misoprostol and then misoprostol alone, presented homogeneously during the distribution of use; in studies, isolated misoprostol was the most indicated option, as it was more associated with the success of induction, resulting in more vaginal deliveries (13).

The risk classification presented homogeneous distribution; although the maternity study had a high-risk prenatal outpatient clinic, women had a usual risk rating of $43.4 \%$ and a high risk of $56 \%$. Following these clinical characteristics of hospitalized women, it is important to consider that the obstetrician nursing professional is qualified and qualified to provide birth care for women classified as habitual risk (1).

In the normal birth group, the variable birth care can be observed that the care provided by the physician (60\%), in relation to the obstetric nursing professional (40\%), predominates in this maternity ward. About this, a study pointed out that the obstetrician nursing professional is a strategic agent in stimulating normal birth aimed at evaluating the well-being of women, fetuses and the evolution of childbirth, following good practices and respect for scientific evidence. Consequently, it strengthens women's empowerment through the exercise of autonomy in the choices for preferences and respect for the expectations of this woman (14).

The nursing team in the birth process with its closest care corroborates the early detection of possible alterations that indicate signs of PPH and may also use some maneuvers to prevent maternal death, in the conduct of situations and management, including the diagnosis of those who are more prone to these risks. The nursing professional can act to bring to the patient the possibility of minor damage to their health, which is why he becomes an indispensable actor to the multidisciplinary team (14). 
It is worth mentioning that, in the variable birth position, in the normal birth group, $65 \%$ experienced verticalization. Throughout humanity, women have chosen to give birth in different positions. Primitive women reached different upright positions, kneeling, crouching, seated, semis-seated, with the aid of sticks, nets, hanging with ropes, and in the vertical position, which became the most popular in history. However, from the technicalization and medicalization of childbirth, most women have horizontal birth because of fear of pain, the search for health safety, lack of freedom of choice, among other factors (15).

Light technologies are characterized as care actions, considered attributes of the human relationship, in which it is possible for professionals to develop quality care through touch, listening to preferences, claims and the use of non-pharmacological methods for pain relief, and the nursing professional obstetrician is the one who has the greatest connection with this practice (16). In this sense, it was possible to observe that the minority ( $25 \%$ ) women received care through light technologies. There was a higher proportion of use of light technologies in the group of normal birth in childbirth care by obstetric nursing professionals compared to physicians ( $p$-value $=0.001$ ), and a statistically significant difference.

When analyzing the variable of breastfeeding in the first hour of life, it is noted in the results of this study that the higher frequency predominated $(81.9 \%)$ of women who did not breastfeed in this "golden hour". There was an association in the bivariate analysis between PPH and non-breastfeeding in the first hour of life ( $p$-value $=0.039$ ). Breastfeeding plays an important role in several aspects and being early, reflects several advantages for women, such as decreased risk of hemorrhage, postpartum depression, increased bond with the child, improvement of postpartum libido, stress reduction and mood (17).

In the multivariate analysis, factors associated with $\mathrm{PPH}$ were identified in multiparous women (with three or more previous pregnancies) who had a prevalence of PPH almost twice. This result corroborates a study that addresses the relationship between the number of pregnancies and maternal mortality, which has PPH as its main cause in the world. Soares, Schor and Tavares (18) analyzed 822 maternal deaths, in which a quarter, 206, were multiparous (five or more pregnancies were six times higher than for women with up to two pregnancies), and sociodemographic and reproductive profiles were more unfavorable for this group of multiparous women. Low schooling, age equal to or above 30 years and prenatal care with less than four consultations were associated with the highest number of pregnancies. The proportion of deaths from indirect obstetric causes, hemorrhages and abortion was higher among multiparous women, and about $90 \%$ of deaths in this group were considered preventable.

When observing the variable of breastfeeding in this study, an important statistical association was found in which not breastfeeding in the first hour of life increased this prevalence by more than four times (Table 3). During breastfeeding, the discharge of hormone that occurs reduces the size of the uterus, releases the placenta, decreases postpartum bleeding, causes a delay of menstruation and consequent prevention of anemia. This effect is mediated by the hormone oxytocin, which is released into the bloodstream during breastfeeding at high levels. The onset of oxytocin release begins at the time of birth for the promotion of uterine contraction. Its action is continuous and enhanced in the act of breastfeeding by the stimulation that suction causes on the pituitary (17).

Oxytocin and prostaglandin hormones play a key role in the third phase of birth, as they are responsible for uterine contraction during this stage. Receptors in uterine muscles are stimulated by exogenous or endogenous oxytocin, leading to uterine contractions. Consequently, these can reduce bleeding during the third stage of labor (19).

It is important to note that, since the mother expels the fetus and the placenta, an important process develops that consists of a powerful uterine contraction caused by natural oxytocin produced by sucking stimulus during breastfeeding, whose function is to close the blood vessels of the uterus, which allows bleeding to be minimal in the mother. When this process does not occur and there is a lack of this production of oxytocin due to the absence of breastfeeding, uterine atony or inertia originates and may have fatal consequences for the parturient, which characterizes one of the three main causes of maternal mortality in the world (20).

\section{Conclusions}

When investigating PPH in women attended in the maternity study, it was possible to identify, in relation to sociodemographic characteristics, the predominance of black women who end up being more susceptible to morbidities that result in maternal death from $\mathrm{PPH}$. Regarding clinical characteristics, there was a high 
prevalence of PPH (38.6\%) and atony (25.6\%), the main cause attributed during the period from January to December 2018. The bivariate analysis showed statistical significance with an association between PPH and non-breastfeeding in the first hour of life $(p=0.039)$.

When observing the factors associated with PPH in the multivariate analysis, it was identified that multiparous women had an increase in the prevalence of PPH by almost twice (PR $=1.97$ ). Not breastfeeding in the first hour of life increased this prevalence more than four times $(P R=4.16)$.

This study suggests the construction of strategies for the reduction of $\mathrm{PPH}$, the reduction of cesarean sections, the expansion of women's access to light care technologies and the implementation of obstetrician nursing professional care in a way that prioritizes respect for the physiology of women during their birth process. It is emphasized that the monitoring of multiparous women and the greater incentive to exclusive breastfeeding in the first hour of life are measures that can contribute to the reduction of the prevalence of $\mathrm{PPH}$ and its complications in this maternity ward.

The results found confirm the magnitude of the frequency of PPH in this maternity ward; although the study had a sample considered small, the cross-sectional design allowed to find associated factors, but without establishing a causal relationship. Considering these limitations, we emphasize the importance of conducting research and scientific evidence on this object and the need for further studies to investigate, in addition to statistical analyses, clinical significance to better understand the implications of PPH for women's health.

Conflict of interest: none declared.

\section{References}

1. Organização Pan-Americana da Saúde. Recomendações assistenciais para prevenção, diagnóstico e tratamento da hemorragia obstétrica. Brasília: OPAS; 2018.

2. Federación Latinoamericana de Asociaciones de Sociedades de Obstetricia y Ginecología. Hemorragia postparto: ¿donde estamos y hacia donde vamos? [internet]. Flasog; 2018. Disponível em: https://portaldeboaspraticas.iff.fiocruz.br/ wp-content/uploads/2018/09/Hemorragia-Postparto-17OCTUBRE.pdf

3. Jauniaux E, Bhide A, Kennedy A, Woodward P, Hubinont C, Collins S. FIGO consensus guidelines on placenta accreta spectrum disorders: Prenatal diagnosis and screening. Int J Gynaecol Obstet. 2018;140(3):274-80. DOI: https://doi. org/10.1002/ijgo.12408

4. Organização Mundial da Saúde. Declaração da OMS sobre taxas de Cesáreas. Genebra: OMS; 2015.

5. Begley CM, Gyte GMI, Devane D, McGuire W, Weeks A, Biety LM. Active versus expectant management for women in the third stage of labour. Cochrane Database Syst Rev. 2019; 2:CD007412. DOI: https://doi.org/10.1002/14651858. CD007412.pub5

6. Martins HEL. Observação em enfermagem: tecnologia para prevenção e controle da hemorragia pós-parto [tese de doutorado em Enfermagem]. Florianópolis: Universidade Federal de Santa Catarina; 2014.

7. Silva LGP, Paula GM. Hemorragia pós-parto. In: Montenegro CAB, Rezende Filho J, editores. Obstetrícia. $13^{\mathrm{a}}$ ed. Rio de Janeiro: Guanabara Koogan; 2016. p. 846-851.

8. Carvalho MVP, Silva TMP, Soares NS, Carvalho ML, Ferreira AKA, Sousa AFL. Mortalidade materna na capital do Piauí. R. Interd. 2014;7(3):17-27. Disponível em: https://revistainterdisciplinar.uninovafapi.edu.br/index.php/revinter/article/ view/265/pdf_133

9. Medeiros LT, Sousa AM, Arinana LO, Inácio AS, Prata MLC, Vasconcelos MNG. Mortalidade materna no estado do Amazonas: estudo epidemiológico. Rev baiana enferm. 2018; 32: e26623. DOI: https://doi.org/10.18471/rbe.v32.26623 
10. Castro BMC, Ramos SCS. Perfil de mortalidade materna em uma maternidade pública da cidade de Manaus-AM. Saúde (Sta Maria). 2016;42(1):103-12. DOI: https://doi.org/10.5902/2236583420953

11. Cheron C, Severo EE. Apanhar ou passar fome? A difícil relação entre dependência financeira e violência. Em: Universidade Federal de Santa Catarina editor. Fazendo Gênero 9: Diásporas, Diversidades, Deslocamentos; 2010 Aug 23-26; Florianópolis, Brasil. c2010. p 1-10. Disponível em: http://www.fazendogenero.ufsc.br/9/resources/anais/1278279902_ ARQUIVO_Cheron_Severo.pdf

12. Takahashi K, Ganchimeg T, Ota E, Vogel JP, Souza JP, Laopaiboon M. Prevalence of early initiation of breastfeeding and determinants of delayed initiation of breastfeeding: Secondary analysis of the WHO Global Survey. Sci Rep. 2017;7:44868. DOI: https://doi.org/10.1038/srep44868

13. Gallos L, Williams H, Price M, Pickering K, Merriel A, Tobias A. Uterotonic drugs to prevent postpartum haemorrhage: A network meta-analysis. Health Technol Assess. 2019;23(9). DOI: https://doi.org/10.3310/hta23090

14. Maya SMG, Pereira V, Paz CT, Barreto FL, Gramacho RCCV, Fraga BGG. A enfermagem obstétrica na prevenção de óbitos por atonia uterina: uma discussão sobre as condutas da enfermagem. Textura. 2018;11(20):9-20. Disponível em: https://textura.famam.com.br/textura/article/view/15

15. Antepara DNC. Percepción sobre el parto en libre posición y el horizontal en mujeres que asisten al Centro de Salud de Biblián 2018. Pol. Con. 2019;4(12):3-21. Disponible en: https://polodelconocimiento.com/ojs/index.php/es/article/ view/1188

16. Ministério da Saúde do Brasil. Departamento de Gestão e Incorporação de Tecnologias em Saúde. Entendendo a incorporação de tecnologias em saúde no sus: como se envolver. Brasília: Ministério da Saúde do Brasil; 2016.

17. Neovita Study Group. Timing of initiation, patterns of breastfeeding, and infant survival: Prospective analysis of pooled data from three randomised trials. Lancet Glob Health. 2016;4(4):e266-e275. DOI: https://doi.org/10.1016/S2214109X(16)00040-1

18. Soares VMN, Schor N, Tavares CM. Vidas arriscadas: uma reflexão sobre a relação entre o número de gestações e mortalidade materna. Rev. Bras. crescimento desenvolv. hum. 2008;18(3):254-63. DOI: https://doi.org/10.7322/jhgd.19888

19. Abedi P, Jahanfar S, Namvar F, Lee J. Breastfeeding or nipple stimulation for reducing postpartum haemorrhage in the third stage of labour. Cochrane Database Syst Rev. 2016;(1):CD010845. DOI: https://doi.org/10.1002/14651858. CD010845.pub2

20. Checa Vera JL, Vizuete Cevallos TJ. Atonía uterina asociada a expulsivo prolongado en mujeres de 15 a 35 años en Hospital Gustavo Domínguez-Santo Domingo de Los Tsachilas, janeiro a junho de 2019 [Proyecto de investigación para la obtención del título de obstetriz/obstetra]. Babahoyo-Los Ríos: Universidad Técnica de Babahoyo; 2019. Disponível em: http://dspace.utb.edu.ec/bitstream/handle/49000/8079/P-UTB-FCS-OSBT-000157.pdf?sequence=1\&isAllowed=y 